\title{
Kesiapan Mahasiswa dalam Pembelajaran Daring dan Hubungannya dengan Hasil Belajar
}

\author{
Dewi Wardah Mazidatur Rohmah', Muhammad Dhika Arif Rizqan² \\ ${ }^{1}$ Universitas Terbuka, Indonesia \\ ${ }^{2}$ Universitas Islam Negeri Sunan Ampel Surabaya, Indonesia
}

DOI: 10.23917/humaniora.v22i2.9460

Submit: 7 Desember 2019. Revisi: 15 April 2020. Diterima: 1 Juli 2021

Available Online: 7 Juli 2021. Periode Terbit: Agustus 2021

\section{Kata Kunci \\ Readiness, \\ online learning, \\ learning outcomes}

\begin{tabular}{l}
\hline Corresponding Author \\
\hline Dewi Wardah Mazidatur \\
Rohmah \\
Universitas Terbuka, Indonesia \\
Email: \\
dewi.rohmah@ecampus.ut.ac.id \\
Telp: +6282232019186
\end{tabular}

Telp: +6282232019186

\section{Abstrak}

Universitas Terbuka (UT), or Open University, has been organizing Pendidikan Tinggi Jarak Jauh (PTJJ), or Distance Learning for Higher Education, since 1984. Along with the changing era, the PTJJ has integrated the use of online technology with the aim that UT students are able to conduct the learning process through online media. The present study aims to measure the level of readiness of UT students in online learning after they received the EKBM (Edukasi Kegiatan Belajar Mandiri) or 'self-directed-learning education activity' lecture and how this readiness affects the results of UT students learning outcomes. The researchers in this study apply a quantitative method. The data are collected through a survey. The respondents are 350 UT students from various majors such as Public Administration, Accounting, Sharia Accounting, Sharia Economics, Communication Study, Librarianship, Management, and Primary Education. The findings showed that Sharia Economics students have a high readiness score while the Management students have a low readiness score. Unexpectedly, the Sharia Economics students have low learning outcomes. On the other hand, Management students have high learning outcomes. It seems that the students that have high readiness score in online learning outcomes could not guarantee the results of their learning outcomes.

\begin{tabular}{l} 
Kata Kunci \\
\hline kesiapan, \\
pembelajaran daring, \\
hasil belajar
\end{tabular}

Universitas Terbuka (UT) sudah menyelenggarakan Pendidikan Tinggi Jarak Jauh (PTJJ) sejak tahun 1984. Seiring dengan perubahan era, PTJJ telah mengintegrasikan penggunaan teknologi daring dengan tujuan agar mahasiswa UT dapat melakukan pembelajaran melalui media daring. Penelitian ini bertujuan untuk mengukur tingkat kesiapan mahasiswa dalam pembelajaran daring setelah mereka menerima kuliah Edukasi Kegiatan Belajar Mandiri (EKBM) dan bagaimana kesiapan ini mempengaruhi hasil belajar mahasiswa UT. Dalam penelitian ini, peneliti menerapakn metode kuantitatif. Data dikumpulkan melalui survei dan respondennya adalah 350 mahasiswa UT dari berbagai program studi, seperti Administrasi Publik, Akuntansi, Akuntansi Syariah, Ekonomi Syariah, Ilmu Komunikasi, Ilmu Perpustakaan, Manajemen, dan Pendidikan Guru Sekolah Dasar (PGSD). Temuan penelitian menunjukan bahwa mahasiswa Ekonomi Syariah memiliki skor kesiapan yang ting- 
gi, sedangkan mahasiswa Manajemen memilki skor kesiapan rendah. Hal yang tak terduga adalah mahasiwa Ekonomi Syariah tersebut memiliki hasil belajar yang rendah. Sementara itu, mahasiswa Manajemen justru memiliki hasil belajar yang tinggi. Tampaknya skor kesiapan tinggi dalam pembelajaran daring tidak dapat menjamin hasil belajar mahasiswa.

\section{PENDAHULUAN}

Sebagai penyelenggara pendidikan tinggi terbuka jarak jauh (PTTJJ) terdepan dan terkemuka di Indonesia, salah satu indikator capaian Universitas Terbuka pada tahun 2019 adalah memperoleh peningkatan dalam capaian hasil belajar mahasiswa. Terdapat beberapa faktor yang dapat mempengaruhi hasil belajar mahasiswa dan salah satunya adalah kesiapan mahasiswa dalam belajar. Dalam konteks PTTJJ, kesiapan ini berupa kesiapan dalam melakukan pembelajaran daring. Dengan semakin meningkatnya persaingan penyediaan pembelajaran daring dalam pendidikan tinggi, sangat penting bagi UT untuk terus meningkatkan pelayanannya, terutama dalam menyiapkan mahasiswa UT untuk mampu belajar mandiri dalam proses pembelajaran daring.

Sejauh ini, UT telah menyelenggarakan program Edukasi Kegiatan Belajar Mandiri (EKBM) yang mencakup Orientasi Studi Mahasiswa Baru (OSMB) dan Pelatihan Keterampilan Belajar Jarak Jauh (PKBJJ). Program-program ini bertujuan untuk mempersiapkan mahasiswa baru dalam menggunakan layanan administratif dan layanan akademik yang ada di UT. Dalam EKBM, mahasiswa juga disiapkan untuk memiliki kemampuan belajar mandiri yang memang sangat diperlukan dalam pembelajaran daring di UT.

Pelaksanaan EKBM tentunya memberi dampak yang signifikan bagi mahasiswa baru UT karena mayoritas mereka belum familiar dengan sistem pembelajaran jarak jauh dan belajar mandiri. Namun, seiring berjalannya masa studi, apakah pengetahuan yang didapatkan selama EKBM masih dilaksanakan oleh mahasiswa? Apakah ada jaminan bahwa mahasiswa yang mengikuti EKBM di awal perkuliahan akan mampu menerapkan pembelajaran mandiri secara daring dengan baik? Dengan adanya permasalahanpermasalahan tersebut, pengukuran tingkat kesiapan mahasiswa dalam menerapkan belajar daring dan belajar mandiri perlu dilakukan, tidak hanya pada mahasiswa baru, tetapi lebih utamanya pada mahasiswa lama. Dengan demikian, institusi dapat memutuskan apakah diperlukan adanya program pendampingan khusus bagi mahasiswamahasiswa UT. Hal ini terkait dengan upaya untuk meningkatkan kesiapan mereka melakukan pembelajaran daring secara mandiri agar proses belajar mahasiswa menjadi lebih efektif. Selain itu, demi meningkatkan kualitas capaian hasil belajar mahasiswa UT, mengetahui apakah tingkat kesiapan mahasiswa dalam melakukan pembelajaran daring secara mandiri mampu memberikan dampak yang signifikan bagi tingkat hasil capaian belajarnya menjadi tak kalah pentingnya. Dengan mengetahui hal-hal tersebut, ini akan membantu stakeholder dan decision maker di UT untuk meningkatkan kualitas layanan akademik bagi mahasiswa UT.

Berdasarkan latar belakang tersebut, penelitian ini berusaha melihat tingkat kesiapan mahasiswa UT dalam belajar mandiri secara daring dan bagaimana kesiapan tersebut berpengaruh pada hasil capaian belajar mahasiswa. Banyak hasil penelitian terdahulu yang telah melakukan investigasi terhadap pengukuran tingkat kesiapan mahasiswa dalam pembelajaran daring. Aspek-aspek yang dapat digunakan untuk mengukur kesia- 
pan mahasiswa dalam pembelajaran daring diambil dari penelitian yang dilakukan oleh Hung et.al (2010) yang meliputi: self-directed learning (belajar mandiri), learner control (kontrol yang dimiliki pembelajar), motivation for learning (motivasi belajar), computer/Internet self- efficacy (kemampuan menggunakan internet/komputer), dan online communication self-efficacy (kemampuan berkomunikasi secara daring) (Kirmizi; 2015, Hao; 2016, Cigdem \& Ozturk; 2016, Yilmaz; 2017, Engin; 2017). Namun, belum ada penelitian yang secara khusus membahas tentang signifikansi kesiapan belajar tersebut pada hasil belajar mahasiswa di berbagai bidang studi dengan lama studi yang beragam. Oleh karena itu, penelitian ini memiliki tujuan utama untuk mengetahui sejauh mana signifikansi tingkat kesiapan belajar daring secara mandiri mahasiswa UT terhadap capaian hasil belajar mahasiswa UT.

Pembelajaran daring (online learning) tidak mudah untuk didefinisikan karena sering dimaknai sama dengan e-learning, technology enhanced learning (pembelajaran berbasis perkembangan teknologi), dan distance learning (pembelajaran jarak jauh). Pada konsepnya, pembelajaran daring mencakup segala kegiatan belajar yang dilakukan secara daring atau melalui media internet. Dengan berkembang pesatnya pendidikan yang dilakukan secara daring, berbagai jenis pembelajaran daring pun menjadi sangat populer dan telah menjadi sebuah pilihan favorit bagi banyak pembelajar usia dewasa (Lee, 2016).

Hal ini tentu erat kaitannya dengan kebutuhan mengenyam pendidikan yang lebih tinggi, tetapi berbenturan dengan keterbatasan waktu yang ada. Itulah sebabnya, tipetipe pembelajar pada konsep pembelajaran daring menjadi sangat bervariasi dengan berbagai macam kebutuhan belajar. Dengan demikian, sudah saatnya konsep pembelajaran daring meninggalkan model one-size fits all (satu untuk semua), agar pembelajaran daring dapat lebih fokus untuk mendukung semua kebutuhan dan tujuan belajar (Kizilcec \& Halawa, 2015).

Pembelajaran daring sendiri memiliki dua keunggulan utama, yaitu dapat mengukur hasil capaian belajar dengan mudah dan dapat menyediakan fleksibilitas dalam hal waktu dan tempat untuk mengakses konten dan pengerjaan tugas. Meskipun pembelajaran daring juga menghadapi berbagai masalah, banyak terobosan dalam pendekatan yang digunakan pada pembelajaran daring telah berhasil meningkatkan potensi pembelajaran daring secara masif. Terobosan tersebut termasuk penggunaan perkuliahan melalui video dan materi yang tersimpan secara daring; penerapan aktifitas belajar yang lebih menarik seperti kuis, games, konten media digital interaktif, serta penggunaan media sosial untuk meningkatkan interaksi sosial bagi pembelajar satu dengan yang lain secara daring dan untuk memfasilitasi peer-assessment (De Freitas et.al, 2015).

Universitas Terbuka, sebagai institusi pendidikan jarak jauh (distance education), telah memiliki berbagai terobosan dalam upaya meningkatkan fasilitas kegiatan pembelajaran daring bagi seluruh mahasiswa UT yang tersebar di Indonesia dan di luar negeri. Tingginya minat peserta pembelajaran daring menunjukkan bahwa pembelajaran daring telah menjadi bagian yang tidak terpisahkan dari proses mengenyam pendidikan bagi masyarakat saat ini. Bahkan, tren pembelajaran daring terlihat memiliki prospek semakin baik kedepannya.

Memulai proses adaptasi terhadap aktivitas kegiatan belajar daring memang tidak mudah, khususnya bagi orang yang tidak familiar dengan teknologi. Mengapa pembelajar pada sistem pembelajaran daring perlu siap untuk melaksanakan proses pembelajaran 
daring? Hal ini erat kaitannya dengan sistem pembelajaran daring yang berbeda dengan pembelajaran di kelas atau pembelajaran tatap muka. Buzdar dkk. (2016) menyebutkan bahwa performa dan perilaku belajar dalam pembelajaran daring sangat berkaitan dengan kesiapan pembelajar dalam beradaptasi dengan pendekatan belajar digital. Dengan tanpa adanya persiapan kemampuan belajar menggunakan media digital, pembelajar akan semakin rentan menghadapi lebih banyak masalah dalam proses pembelajaran daring.

Kemampuan belajar mandiri telah menjadi salah satu sub-aspek dalam kesiapan belajar daring (Yilmaz, 2017). Buzdar dkk. (2016) telah menginvestigasi empat aspek dari kesiapan pembelajar untuk melaksanakan pembelajaran daring. Pembelajar yang berhasil melaksanakan pembelajaran daring ternyata memiliki kesiapan yang cukup besar dalam aspek motivasi dan kemampuan belajar mandiri. Hal ini dapat terjadi karena dalam proses pembelajaran daring, fleksibilitas akses yang diberikan juga menuntut adanya kemandirian pembelajar dalam melaksanakan proses belajarnya. Itulah sebabnya pembelajaran secara daring tak bisa dipisahkan dari kemampuan belajar mandiri.

Peningkatan kebutuhan jumlah pelaksanaan pembelajaran daring juga memunculkan kebutuhan untuk memahami seperti apakah cara terbaik untuk mengaplikasian kemampuan belajar mandiri sehingga kemampuan itu menjadi strategis dan efektif dalam meningkatkan pencapaian akademik pembelajar dalam proses belajar daring (Broadbent dan Poon, 2015).

Dalam upaya meningkatkan hasil capaian belajar bagi pembelajar yang melaksanakan proses belajar daring, telah banyak penelitian yang mengeksplorasi kesiapan pembelajar untuk melaksanakan kegiatan belajar daring (Kirmizi, 2015; Hao, 2016; Cigdem dan Ozturk, 2016; Yilmaz, 2017; Engin, 2017). Faktanya, kemampuan belajar mandiri adalah salah satu faktor yang dilihat secara mendalam karena faktor ini memiliki dampak besar pada keberhasilan proses belajar daring.

Kemampuan belajar mandiri tidak dapat dipaksakan, tetapi harus muncul dari diri pembelajar sendiri. Mereka yang telah mampu melaksanakan proses pembelajaran secara daring, secara tidak langsung telah menggunakan beberapa strategi belajar mandiri sehingga menyebabkan mereka merasa nyaman melaksanakan proses pembelajaran daring yang menyediakan lingkungan yang autonomous (memberikan kebebasan akses) (Broadbent, 2017). Broadbent (2017) lebih lanjut menerangkan bahwa perbedaan capaian hasil belajar bagi pembelajar yang sama-sama telah mampu menggunakan kemampuan belajar mandiri ternayata dipengaruhi oleh gaya belajar yang berbeda antara pembelajar satu dengan yang lain.

Bagi pembelajar yang melakukan pembelajaran daring, kemampuan manajemen waktu dan strategi regulasi belajar adalah hal yang juga memberi pengaruh cukup besar dalam capaian hasil belajarnya. Asumsi yang umum diketahui menyatakan bahwa pembelajaran daring bersifat autonomous sehingga sangat wajar jika kedua kemampuan (kemampuan manajemen waktu dan strategi regulasi belajar) yang termasuk dalam kemampuan belajar mandiri tersebut dapat mempengaruhi hasil belajar dari sisi akademis. Pembelajar yang mampu belajar mandiri akan mampu secara efektif melakukan penjadwalan, perencanaan, dan manajemen waktu belajar sembari secara tepat mengalokasikan penggunaan sumber-sumber belajar, meskipun dihadapkan dengan berbagai gangguan (Broadbent, 2017) 
Studi yang dilakukan oleh Lee (2016) menemukan bahwa otonomi pembelajar (kemampuan pembelajar untuk belajar mandiri) harus dimiliki dalam implementasi berbagai jenis bentuk pembelajaran daring. Dalam hal ini, desain pembelajaran daring yang baik juga menjadi krusial. Namun, sebagus apapun desain pembelajarannya, jika orang yang melaksanakan proses belajar daring tidak mampu melaksanakan proses belajar mandiri dengan baik, hasil belajarnya tidak akan maksimal.

Dalam proses pembelajaran konvensional (kelas tatap muka) dan pembelajaran daring, hasil capaian belajar secara akademis didefinisikan sebagai capaian tertentu dalam tugas, ujian, mata kuliah/mata pelajaran, atau gelar tertentu, dan biasanya diwujudkan dalam bentuk nilai numerik atau poin rata-rata (Richardson, dkk., 2012 dalam Broadbent dan Poon, 2015). Hasil capaian belajar dapat dipengaruhi berbagai faktor, tetapi dalam proses pembelajaran daring, faktor-faktor yang mempengaruhi hasil belajar menjadi sedikit berbeda dari pembelajaran tatap muka.

Broadbent (2017) menyimpulkan bahwa dari sekian banyak literatur yang meneliti tentang hasil capaian belajar dalam konteks pembelajaran daring, sangat jelas bahwa kemampuan belajar mandiri adalah faktor yang sangat berpengaruh. Means, dkk. (2009 dalam Broadbent, 2017) juga menegaskan bahwa pembelajar yang melakukan proses belajar daring dan blended (bauran/campuran antara daring dan tatap muka) memiliki hasil belajar yang lebih baik dibandingkan pembelajar yang hanya melaksanakan proses belajar tatap muka

Sebuah meta-analisis yang dilakukan oleh Broadbent dan Poon (2015) menyimpulkan bahwa hanya ada empat strategi belajar yang berhubungan secara signifikan dengan nilai hasil belajar pada proses pembelajaran daring, yaitu: metakognisi, manajemen wak$\mathrm{tu}$, pengaturan usaha belajar, dan kemampuan berpikir kritis (dalam Broadbent, 2017). Sementara itu, dalam latihan belajar daring, kemampuan mengembangkan ide dan kemampuan mengorganisasi informasi memiliki dampak yang tidak terlalu signifikan pada hasil belajar daring (Broadbent dan Poon, 2015). Lebih leangkapnya, aspek kesiapan belajar yang meliputi self-directed learning (belajar mandiri), learner control (kontrol yang dimiliki pembelajar), motivation for learning (motivasi belajar), computer/Internet self-efficacy (kemampuan menggunakan internet/komputer), dan online communication self-efficacy (kemampuan berkomunikasi secara daring) yang dikembangkang oleh Hung, dkk. (2010) telah mencakup semua aspek yang dibutuhkan dalam proses belajar daring.

Motivasi pembelajar untuk melaksanakan kegiatan belajar tentu juga termasuk dalam cakupan aspek yang mendukung proses pembelajaran daring. Motivasi ini dapat dipengaruhi oleh kesiapan belajar sehingga dapat menentukan apakah pembelajar mampu memanfaatkan kesempatan belajar daring sebaik-baiknya atau malah menjadi lebih tidak semangat belajar. Dengan adanya interaksi sosial yang terbatas dalam proses belajar daring, stimulasi berupa kegiatan belajar berkelompok melalui membangun komunitas daring sangat diperlukan agar pembelajar menjadi lebih semangat belajar dan dapat belajar lebih mandiri (Lee, 2016). Dengan faktor-faktor kompleks yang harus dianalisis dalam konteks kesiapan belajar daring, mengetahui seberapa besar dampak yang dihasilkan oleh berbagai tingkatan kesiapan mahasiswa UT dalam melaksanakan pembelajaran daring terhadap hasil belajar menjadi hal yang menarik untuk dikaji.

\section{METODE}


Penelitian ini menggunakan kuisioner sebagai intrumen utama. Untuk teknik pengambilan sampel data, purposive random sampling digunakan untuk menentukan daftar responden dan responden yang dipilih hanya mahasiswa UT lintas program studi yang terdaftar di UPBJJ-UT Surabaya, yang setidaknya telah melaksanakan proses belajar selama satu semester di UT. UPBJJ-UT Surabaya dipilih dengan pertimbangan bahwa UPBJJ-UT Surabaya memiliki jumlah mahasiswa terbanyak keempat dari seluruh UPBJJ di Indonesia. UPBJJ-UT ini juga terletak di Surabaya, yang merupakan kota terbesar kedua di Indonesia sehingga bidang studi yang diambil oleh mahasiswa di UPBJJ-UT Surabaya pun beragam. Dengan berbagai latar belakang mahasiswanya, polemik lama studi juga terjadi di UPBJJ-UT Surabaya sehingga pengelompokan lama studi dalam penelitian ini dapat menjadi lebih bervariasi. Berbagai karakteristik mahasiswa UPBJJ-UT Surabaya itulah yang akan membuat hasil penelitian ini lebih menarik dan lebih representatif.

Pengambilan data dilakukan selama 5 minggu dengan menyebar kuisioner secara online dan offline. Kuisioner online dimasukkan pada google form yang link nya dapat diakses oleh para responden. Cara ini digunakan untuk memudahkan akses pengumpulan data karena kebanyakan mahasiswa UT tersebar di beberapa kota yang berbeda. Sebanyak 350 kuesioner telah disebarkan dan dikumpulkan dari mahasiswa UT di UPBJJ-UT Surabaya. Dalam proses pengisian kuisioner, mahasiswa memberikan informasi atas permasalahan yang diangkat dalam penelitian ini. Apabila data yang didapatkan masih kurang, peneliti dapat menambah jumlah responden.

Penelitian ini menggunakan metode penelitian kuantitatif dengan mengaplikasikan Teknik Korelasi Spearman yang dihitung menggunakan SPSS untuk mengetahui hasil dari permasalahan yang ingin diteliti. Tingkat kesiapan tersebut kemudian dikorelasikan dengan hasil capaian belajar mahasiswa yang dianalisis menggunakan penghitungan kriteria pengujian. Kriteria ini menentukan apakah suatu korelasi dapat dikatakan memiliki hubungan yang signifikan antara tingakat kesiapan belajar daring dan hasil belajar, apabila nilai < level of significance $(\alpha=10 \%$ atau 0,1$)$.

Variabel bebas dalam penelitian ini adalah kesiapan belajar daring, sedangkan variabel terikatnya adalah hasil capaian belajar mahasiswa UT. Hipotesis yang dibuat untuk melihat hubungan antara variabel kesiapan belajar daring dengan hasil capaian belajar yang berada pada cakupan rumusan masalah dalam penelitian ini adalah sebagai berikut.

a. Null Hypothesis (H0): tidak terdapat hubungan yang signifikan antara kesiapan belajar daring dengan hasil capaian belajar

b. Alternate hypothesis (H1): terdapat hubungan yang signifikan antara kesiapan belajar daring dengan hasil capaian belajar.

Dalam pengujian hipotesis, interpretasi analisis Spearman dari nilai koefisien korelasi dari hasil perhitungan adalah:

a. Jika nilai koefisien menunjukkan korelasi positif, maka hubungan antara variabel bebas dengan variabel terikat berarti berupa hubungan yang searah sehingga meningkatnya variabel bebas akan menyebabkan meningkatnya variabel terikat.

b. Jika nilai koefisien menunjukkan korelasi negatif, maka hubungan antara variabel bebas dengan variabel terikat adalah berupa hubungan yang berlawanan sehingga meningkatnya variabel bebas akan menyebabkan menurunnya variabel terikat. 


\section{HASIL DAN PEMBAHASAN}

Fokus penelitian ini adalah signifikansi kesiapan belajar pada hasil belajar mahasiswa di berbagai lintas bidang studi dengan lama studi yang beragam. Namun, sebelum melakukan pengujian signifikansi tersebut dilakukan analisis identifikasi karakteristik responden serta identifikasi variabel kesiapan belajar dan hasil belajar mahasiswa UT.

Deskripsi data menjelaskan mengenai deskripsi variabel yang diteliti yang meliputi fakultas, program studi, semester, kesiapan kerja, dan hasil belajar. Hasil deskripsi data dapat dijelaskan pada Tabel 1. berikut.

Tabel 1. Deskripsi data fakultas pada mahasiswa UT

\begin{tabular}{lll}
\hline Fakultas & Frekuensi & Persentase \\
\hline FE & 184 & 52,6 \\
FHISIP & 136 & 38,9 \\
FKIP & 29 & 8,3 \\
Pascasarjana & 1 & 0,3 \\
\hline Total & $\mathbf{3 5 0}$ & $\mathbf{1 0 0 , 0}$ \\
\hline
\end{tabular}

Keterangan

FE : Fakultas Ekonomi

FHISIP : Fakultas Hukum, Ilmu Sosial, dan Ilmu Politik

FKIP : Fakultas Keguruan dan Ilmu Pendidikan

Berdasarkan sajian data pada Tabel 1, diketahui bahwa dari total 350 mahasiswa UT pada penelitian ini sebagian besar responden adalah mahasiswa pada FE sebesar 52,6\%. Mahasiswa FHISIP adalah sebesar 38,9\%, sedangkah FKIP adalah sebesar 8,3\%. Sisanya, hanya sebesar 0,3\% responden berada di Pascasarjana.

Tabel 2. Deskripsi data program studi mahasiswa UT

\begin{tabular}{lll}
\hline Program Studi & Frekuensi & Persentase \\
\hline Administrasi Negara & 75 & 21,4 \\
Akuntansi & 8 & 2,3 \\
Akutansi syariah & 1 & 0,3 \\
Ekonomi Syariah & 1 & 0,3 \\
Ilmu Komunikasi & 24 & 6,9 \\
Ilmu Perpustakaan & 37 & 10,6 \\
Manajemen & 175 & 50,0 \\
PGSD & 29 & 8,3 \\
\hline Total & $\mathbf{3 5 0}$ & $\mathbf{1 0 0 , 0}$
\end{tabular}

Berdasarkan sajian data pada Tabel 2, diketahui bahwa dari total 350 mahasiswa UT yang dijadikan sampel pada penelitian ini, didapatkan hasil bahwa mayoritas responden mengambil program studi Manajemen sebesar 50,0\%. Mahasiswa UT yang mengambil program studi Administrasi Negara sebesar 21,4\%, dan sebesar 10,6\% mahasiswa UT mengambil program studi Ilmu Perpustakaan. Sisanya adalah mahasiswa yang mengambil program studi PGSD sebesar 8,3\%, Ilmu Komunikasi sebesar 6,9\%, Akuntansi sebesar 2,3\%, Akutansi syariah sebesar 0,3\%, dan Ekonomi Syariah sebesar $0,3 \%$. 
Tabel 3. Deskripsi data semester pada mahasiswa UT

\begin{tabular}{lll}
\hline Semester & Frequency & Percent \\
\hline 2 & 47 & 13,4 \\
3 & 147 & 42,0 \\
4 & 48 & 13,7 \\
5 & 66 & 18,9 \\
7 & 42 & 12,0 \\
\hline Total & $\mathbf{3 5 0}$ & $\mathbf{1 0 0 , 0}$ \\
\hline
\end{tabular}

Berdasarkan sajian data pada Tabel 3, diketahui bahwa dari total 350 mahasiswa UT pada penelitian ini, didapatkan hasil bahwa sebagian besar responden berada pada semester 3 yaitu sebesar 42,0\%. Mahasiswa UT yang berada pada semester 5 sebesar $18,9 \%$, dan sebesar $13,7 \%$ responden adalah mahasiswa seemster 4 . Sisanya adalah mahasiswa UT yang menempuh semester 2 sebesar 13,4\%, dan semester 7 sebesar $12,0 \%$.

\section{Tingkat kesiapan belajar daring dan capaian hasil belajar mahasiswa UT}

Berdasarkan hasil pada grafik 1, diketahui bahwa program studi Ekonomi Syariah memiliki kesiapan belajar daring secara mandiri yang tinggi, tetapi memiliki hasil belajar dengan rata-rata yang paling rendah. Berbeda halnya dengan mahasiswa Program Studi Manajemen yang memiliki kesiapan belajar daring secara mandiri yang paling rendah, tetapi hasil belajar nya lebih tinggi dibandingkan kesiapan belajar daringnya. Ini sangat berbeda dengan program studi Administrasi Negara, Akuntansi Syariah, Ekonomi Syariah, Ilmu Komunikasi, dan Ilmu perpustakaan yang memiliki kesiapan belajar daring lebih tinggi apabila dibandingkan dengan hasil capaian belajarnya.

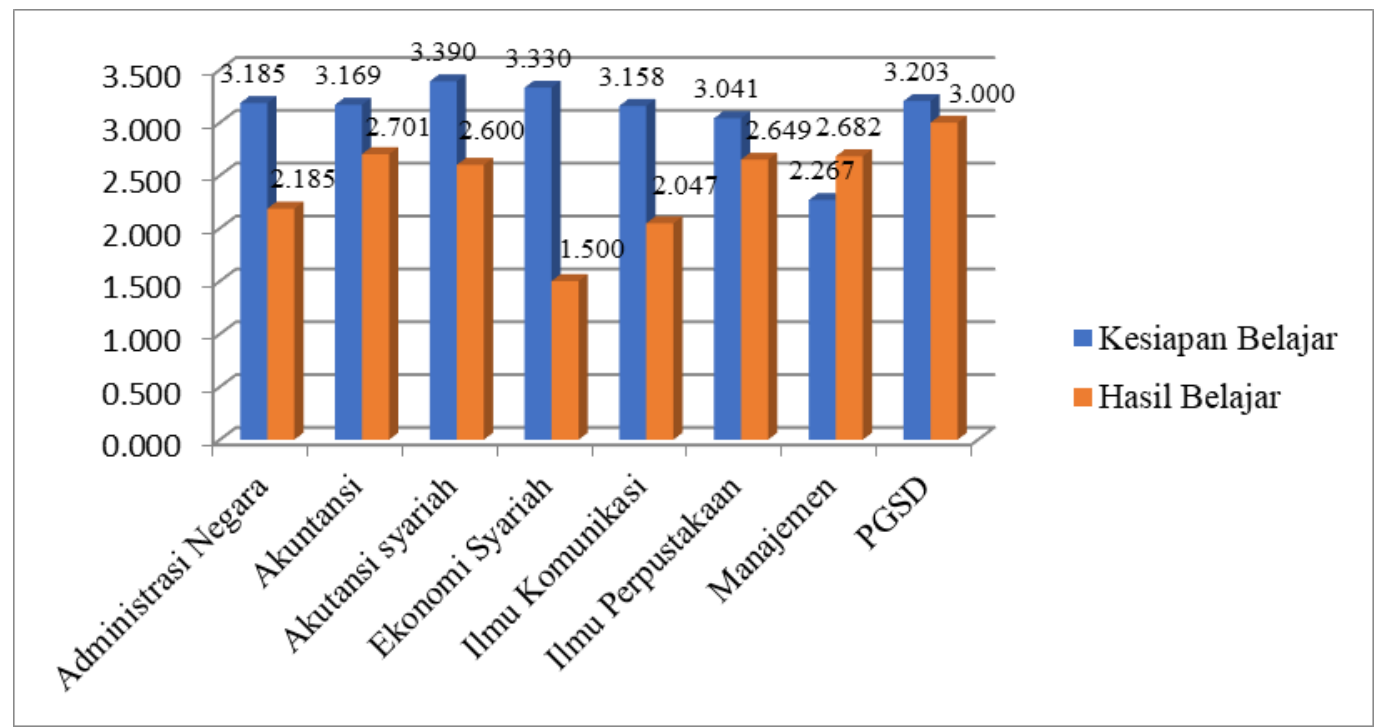

Grafik 1. Tingkat Kesiapan Belajar Daring secara Mandiri terhadap Capaian Belajar Mahasiswa UT Berdasarkan Program Studi

Temuan pada mahasiswa program studi (prodi) manajemen ini tentu menarik. Sebagaimana telah dibahas sebelumnya, masukan mahasiswa prodi manajemen ini 
heterogen dan prodi ini cukup populer di UT. Hal ini sangat mungkin menjadi faktor penyebab lebih tingginya tingkat capaian belajar mahasiswa dibandingkan kesiapan belajar daring nya.

Gap yang sangat besar antara kesiapan belajar daring dan hasil capaian belajar mahasiswa terlihat pada prodi Ekonomi Syariah. Kesiapan belajarnya mencapai skor 3.330, sedangkan hasil capaian belajarnya hanya mencapai 1.500 yaitu capaian belajar terendah jika dibandingkan dengan prodi lain. Temuan ini sangat bisa diprediksi mengingat bahwa prodi Ekonomi Syariah ini adalah prodi baru yang bahkan modul yang digunakan masih modul milik prodi Ekonomi (umum) dan belum diperbarui. Analisis juga bisa dilakukan dengan melihat latar belakang mayoritas masukan mahasiswa yang mengambil Ekonomi Syariah. Mayoritas mahasiswa yang mengambil Ekonomi Syariah adalah mereka yang tinggal di pesantren, karena UT juga memiliki relasi kemitraan yang erat dengan berbagai pesantren ternama. Dengan tinggal dipesantren, hal ini mungkin juga membuat jadwal mahasiswa menjadi lebih padat dibandingkan mahasiswa lain sehingga proses pelaksanaan belajar mandirinya kurang maksimal. Hal ini kemudian berimbas pada rendahnya hasil capaian belajar mahasiswa.

Program Studi Akuntansi dan Pascasarjana menghasilkan kecenderungan yang seimbang antara kesiapan belajar daring secara mandiri dengan hasil belajar. Hal ini ditunjukkan dengan tingkat kesiapan belajar daring tinggi yang juga diikuti capaian hasil belajar yang tinggi.

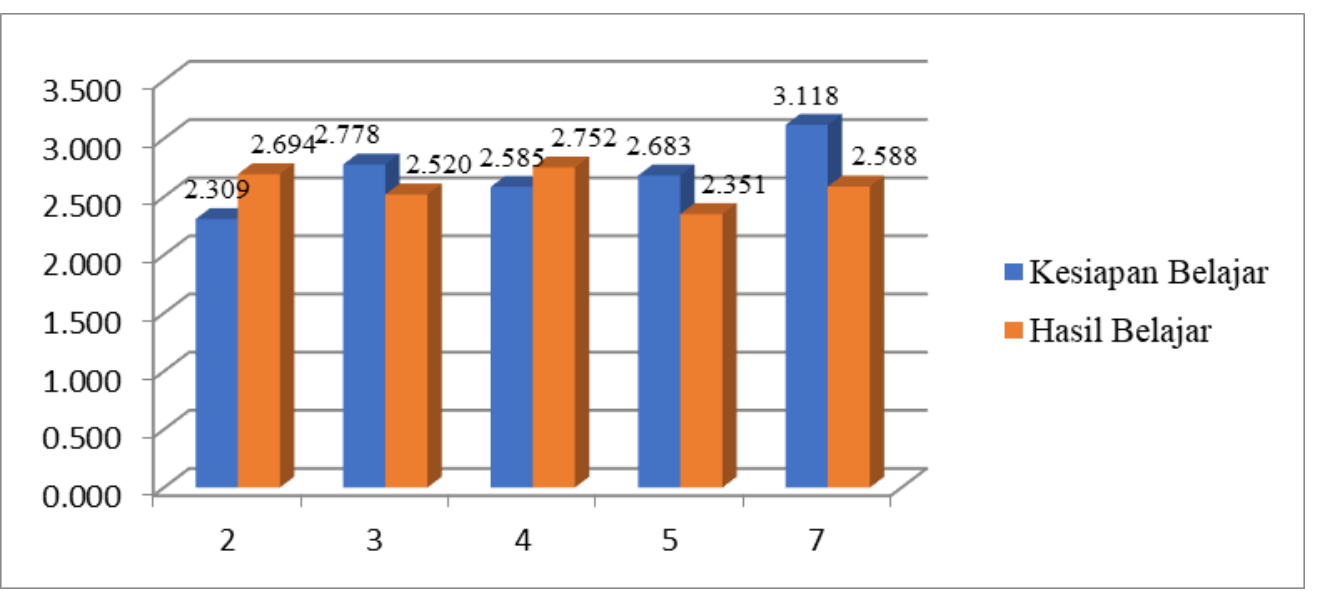

Grafik 2. Tingkat Kesiapan Belajar Daring secara Mandiri terhadap Capaian Hasil Belajar Mahasiswa UT Berdasarkan Semester

Ketika dilihat perbandingan kesiapan belajar daring dan hasil capaian belajar berdasarkan hasil pada grafik di grafik 2, dapat diketahui bahwa mahasiswa semester 2 dan 4 memiliki kesiapan belajar daring secara mandiri yang rendah, tetapi memiliki capaian hasil belajar dengan rata-rata yang tinggi. Pada semester 3, 5, dan 7, terlihat kecenderungan yang seimbang antara kesiapan belajar daring secara mandiri dengan hasil belajar. Hal ini ditunjukkan dengan tingkat kesiapan belajar daring tinggi yang juga diikuti capaian hasil belajar yang tinggi. Ini terjadi karena beban mata kuliah pada semester genap yang, pada beberapa prodi, memiliki tingkat kesulitan mata kuliah yang lebih mudah apabila dibandingkan dengan semester ganjil. 


\section{Signifikansi tingkat kesiapan belajar daring dan capaian hasil belajar mahasiswa} UT

Analisis signifikansi menjelaskan mengenai hubungan Tingkat Kesiapan Belajar Daring secara Mandiri Mahasiswa UT terhadap Capaian Hasil Belajar Mahasiswa UT. Pengujian hubungan dilakukan dengan analisis korelasi. Namun, untuk mengetahui jenis analisis korelasi yang tepat, diakukan pengujian asumsi normalitas terlebih dahulu. Berikut adalah penjelasan dari hasil uji normalitas dan analisis korelasi.

Uji asumsi normalitas dimaksudkan untuk mengetahui apakah data yang akan dianalisis berdistribusi normal atau tidak. Untuk mendeteksi apakah data berdistribusi normal atau tidak, dapat dilihat melalui statistik uji Kolmogorov Smirnov. Data dinyatakan berdistribusi normal apabila nilai probability lebih dari significant alpha $(5 \%$ atau 0,05). Berikut ini adalah hasil pengujian asumsi normalitas melalui statistik uji Kolmogorov Smirnov:

Tabel 4. Hasil uji asumsi normalitas

\begin{tabular}{lll}
\hline Variabel & Statistik Uji & Signifikansi \\
\hline Tingkat Kesiapan Belajar & 0,171 & 0,000 \\
Hasil Belajar & 0,040 & 0,200 \\
\hline
\end{tabular}

Berdasarkan tabel 4, diketahui bahwa pengujian normalitas pada variabel Tingkat Kesiapan Belajar menghasilkan nilai signifikansi sebesar 0,000. Nilai signifikansi tersebut adalah < significant alpha $(5 \%$ atau 0,05$)$. Oleh karena itu, data variabel Tingkat Kesiapan Belajar dinyatakan tidak berdistribusi normal. Dengan demikian, dikarenakan asumsi normalitas tidak terpenuhi pada salah satu variabel, maka analisis korelasi pearson tidak dapat digunakan. Sebagai alternatifnya, telah digunakan analisis korelasi spearman.

Pengujian hubungan antara Tingkat Kesiapan Belajar Daring Secara Mandiri Mahasiswa UT Terhadap Capaian Hasil Belajar Mahasiswa UT dilakukan dengan menerapkan analisis korelasi spearman. Dalam kriteria pengujian ini, suatu hasil dikatakan terdapat hubungan yang signifikan apabila nilai Significance < level of significance $(\alpha=$ $5 \%$ atau 0,05$)$. Hasil pengujian hubungan antara variabel dapat diketahui melalui Tabel 5.

Tabel 5. Hasil Uji Hubungan Tingkat Kesiapan Belajar dan Hasil Belajar

\begin{tabular}{llll}
\hline Variabel 1 & Variabel 2 & $\begin{array}{l}\text { Koefisien } \\
\text { Korelasi }\end{array}$ & Signifikansi \\
\hline Tingkat Kesiapan Belajar & Hasil Belajar & 0,104 & 0,052 \\
\hline
\end{tabular}

Hasil pengujian dalam tabel 5 mengenai hubungan Tingkat Kesiapan Belajar Daring Secara Mandiri Mahasiswa UT terhadap Capaian Hasil Belajar Mahasiswa UT menghasilkan nilai signifikansi dari analisis korelasi spearman sebesar 0,052. Hasil ini menunjukkan bahwa nilai signifikansi < level of significance $(\alpha=10 \%$ atau 0,1$)$. Dengan demikian, dapat dinyatakan bahwa terdapat hubungan yang cukup signifikan antara Tingkat Kesiapan Belajar Daring Secara Mandiri Mahasiswa UT terhadap Capaian Hasil Belajar Mahasiswa UT. Temuan ini mengindikasikan bahwa kesiapan belajar daring berhubungan dengan hasil capaian belajar secara signifikan. Dengan demikian, 
alternate hypothesis (H1) yang menyatakan bahwa "terdapat hubungan yang signifikan antara kesiapan belajar daring dengan hasil capaian belajar" diterima, dan Null Hypothesis (H0) yang menyatakan bahwa "tidak terdapat hubungan yang signifikan antara kesiapan belajar daring dengan hasil capaian belajar" ditolak.

Berdasarkan data, juga dapat diinterpretasikan bahwa yang paling utama pada pembelajaran jarak jauh adalah proses belajarnya, yaitu ketika mahasiswa dapat mengakrabkan diri dengan sistem belajar yang menuntut kemandirian. Belum tentu mahasiswa yang kesiapan belajar daring nya tinggi akan secara otomatis memiliki nilai capaian hasil belajar yang tinggi. Hal ini ditunjukkan dengan data yang menunjukkan bahwa tingkat kesiapan belajar daring mahasiswa belum secara signifikan dapat menjadi prediktor hasil capaian belajarnya dengan Nilai koefisien yang dihasilkan dari analisis sebesar 0,104, yang menunjukkan bahwa keeratan hubungan Tingkat Kesiapan Belajar Daring Secara Mandiri Mahasiswa UT terhadap Capaian Hasil Belajar Mahasiswa UT dalam kategori korelasi positif yang lemah (Lind, 2012).

\section{SIMPULAN}

Berdasarkan hasil penelitian ini, dapat disimpulkan bahwa kesiapan belajar daring mahasiswa UT cukup tinggi karena dari skala 1-4, rata-rata nilai kesiapan belajar daring mahasiswa UT mencapai skor kisaran 3. Banyak faktor yang mempengaruhi tingkat kesiapan belajar daring mahasiswa UT. Faktor ini termasuk diantaranya adalah permasalahan apakah mahasiswa sudah terbiasa dengan sistem belajar daring yang menuntut adanya belajar mandiri atau tidak. Itulah sebabnya mahasiswa pada semester 7 memiliki tingkat kesiapan belajar daring yang paling tinggi dibandingkan dengan mahasiswa UT yang masih pada semester 2, 3, 4, dan 5. Selain itu, kepopuleran program studi juga tidak menjamin tingkat kesiapan belajar daring yang tinggi. Hal ini justru dapat membuat rata-rata skor tingkat kesiapan belajar daring mahasiswa yang mengambil prodi tersebut menjadi rendah. Hal ini terjadi karena tingkat heterogenitas mahasiswa pada prodi cukup tinggi.

Signifikansi antara kesiapan belajar daring mahasiswa UT dan hasil capaian belajar menunjukkan hubungan signifikansi positif yang lemah. Hal ini mengindikasikan bahwa kesiapan berlajar daring bukan prediktor yang kuat terhadap kesuksesan belajar mahasiswa yang di dalam penelitin ini diukur dengan nilai IPK. Fakta bahwa mahasiswa yang kesiapan belajar daringnya tinggi belum tentu memiliki kecenderungan nilai capaian hasil belajar yang tinggi telah mengungkap bahwa poin penting dalam kesuskesan belajar jarak jauh, yang pada kasus ini diukur dengan IPK, adalah familiaritas mahasiswa dengan sistem belajar jarak jauh yang menuntut kemandirian dan motivasi dari diri pembelajar.

\section{DAFTAR PUSTAKA}

Broadbent, J. (2017). Comparing online and blended learner's self-regulated learning strategies and academic performance. The Internet and Higher Education, 33, 24-32. https://doi.org/10.1016/j.iheduc.2017.01.004

Broadbent, J., \& Poon, W. L. (2015). Self-regulated learning strategies \& academic achievement in online higher education learning environments: A systematic review. The Internet and Higher Education, 27, 1-13. https://doi.org/10.1016/j.iheduc.2015.04.007 
Buzdar, M., Ali, A., \& Tariq, R. (2016). Emotional intelligence as a determinant of readiness for online learning. The International Review of Research in Open and Distributed Learning, 17(1). Pp. 148-158. https://doi.org/10.19173/irrodl.v17i1.2149

Cigdem, H., \& Ozturk, M. (2016). Critical components of online learning readiness and their relationships with learner achievement. Turkish Online Journal of Distance Education, 17(2).

De Freitas, S. I., Morgan, J., \& Gibson, D. (2015). Will MOOCs transform learning and teaching in higher education? Engagement and course retention in online learning provision. British Journal of Educational Technology, 46(3), 455-471. DOI: 10.1111/bjet.12268

Engin, M. (2017). Analysis of Students' Online Learning Readiness Based on Their Emotional Intelligence Level. Universal Journal of Educational Research, 5(n12A), 32-40. DOI: 10.13189/ujer.2017.051306

Hao, Y. (2016). Exploring undergraduates' perspectives and flipped learning readiness in their flipped classrooms. Computers in Human Behavior, 59, 82-92. DOI: https://doi.org/10.1016/j.chb.2016.01.032

Hung, M. L., Chou, C., Chen, C. H., \& Own, Z. Y. (2010). Learner readiness for online learning: Scale development and student perceptions. Computers \& Education, 55(3), 1080-1090. https://doi.org/10.1016/j.compedu.2010.05.004

Kırmızı, Ö., \& Kömeç, F. (2019). The impact of the flipped classroom on receptive and productive vocabulary learning. Dil ve Dilbilimi Çalışmaları Dergisi, 15(2), 437-449. DOI: 10.17263/j1ls.586096

Kizilcec, R. F., \& Halawa, S. (2015, March). Attrition and achievement gaps in online learning. In Proceedings of the second (2015) ACM conference on learning@ scale (pp. 57-66). https://doi.org/10.1145/2724660.2724680

Lee, L. (2016). Autonomous learning through task-based instruction in fully online language courses. Language Learning \& Technology. 20(2), 81-97.

Lind, D. A., Marchal, W. G., \& Wathen, S. A. (2012). Statistical techniques in business \& economics. New York, NY: McGraw-Hill/Irwin.

Yilmaz, R. (2017). Exploring the role of e-learning readiness on student satisfaction and motivation in flipped classroom. Computers in Human Behavior, 70, 251-260. DOI: 10.1016/j.chb.2016.12.085 